\title{
PROSES PEMBUATAN KEBIJAKAN PEMBAGIAN KEWENANGAN ANTAR TINGKAT PEMERINTAHAN DALAM PENGELOLAAN HUTAN LINDUNG DAN IMPLEMENTASINYA DI TINGKAT KABUPATEN (Policy Making Process of Authorities Among Levels of Government in The Protected Forest Management and Its Implementation in The Regency Level)
}

$\mathrm{Oleh} / \mathrm{By}$ :

Sulistya Ekawati ${ }^{1}$, Hariadi Kartodihardjo ${ }^{2}$, Hardjanto ${ }^{3}$, Haryatno Dwiprabowo ${ }^{4} \&$ Dodik Ridho Nurrochmat ${ }^{5}$

${ }^{1,4}$ Puslitbang Perubahan Iklim dan Kebijakan, Jl Gunung Batu No 5, Telp/Fax. (0251) 8633944/8634924, E-mail: ekawati69@yahoo.com

${ }^{2,3,5}$ Fakultas Kehutanan IPB, Jalan Lingkar Akademik Kampus IPB Darmaga, Telp. (0251) $8621677 / 8621256$

\begin{abstract}
The process of policy-making on the division of authority between levels of governance put the management of protected forests under the authority of Regency Government. After a decade of running the policy, deforestation in protected forests still continues. This study aims to understand how the policy on the division of authority among levels of government was formulated and implemented. The study was conducted in three regencies in the watershed Batanghari (Regency of East Tanjung Jabung, Sarolangun and South Solok), by analyzing the evaluation of policymaking process and seeing its implementation. The results showed that the performance management of protected forests is determined by the policy formulation and policy implementation in the field. Changes in forest cover to non-forest showes that the existing policy bave proven ineffective. The case of the division of authority between levels of government indicate that the process and implementation of policies do not run linearly. Discourse and knowledge that were developing, the actors and the networks would determine the birth of a policy.
\end{abstract}

Key words: Decentralization, management, protected forest, narrative policy, performance

\begin{abstract}
ABSTRAK
Proses pembuatan kebijakan pembagian kewenangan antar tingkat pemerintahan menempatkan pengelolaan hutan lindung menjadi kewenangan Pemerintah Kabupaten. Setelah satu dekade kebijakan tersebut berjalan, deforestasi di hutan lindung terus berlanjut. Kajian ini bertujuan untuk mengevaluasi bagaimana kebijakan pembagian kewenangan antar tingkat pemerintahan dirumuskan dan diimplementasikan. Kajian dilakukan di tiga Kabupaten dalam DAS Batanghari (Kabupaten Tanjung Jabung Timur, Kabupaten
\end{abstract}


Proses Pembuatan Kebijakan Pembagian Kewenangan antara ... . Sulistya EKawati, Hariadi Kartodifardjo, Hardjanto, Haryatno Dwiprabowo ${ }^{\circ}$ Dodik Ridho Nurrochmat

Sarolangun dan Kabupaten Solok Selatan), dengan melakukan analisis evaluasi proses pembuatan kebijakan dan melihat implementasinya. Hasil penelitian menunjukkan bahwa kinerja pengelolaan hutan lindung ditentukan oleh perumusan kebijakan dan implementasi kebijakan di lapangan. Perubahan tutupan hutan menjadi non hutan menunjukkan bahwa kebijakan yang ada terbukti belum efektif. Kasus pembagian kewenangan antar tingkat pemerintahan menunjukkan bahwa proses dan implementasi kebijakan tidak berjalan linier. Diskursus dan pengetahuan yang berkembang, aktor serta jaringannya menentukan lahirnya sebuah kebijakan.

Kata kunci: Desentralisasi, pengelolaan, hutan lindung, narasi kebijakan, kinerja

\section{PENDAHULUAN}

Desentralisasi mensyaratkan pembagian kewenangan antar tingkat pemerintahan. Di awal kebijakan desentralisasi diberlakukan, pembagian kewenangan antar tingkat pemerintahan diatur dalam PP No 25 tahun 2000 tentang Kewenangan Pemerintah dan Kewenangan Provinsi sebagai Daerah Otonom. Perundangan tersebut menganut sistem open end arrangement, pembagian kewenangan dilakukan dengan menyebutkan secara rinci kewenangan yang dimiliki oleh pemerintah pusat di dalam undang-undang. Sisa kewenangan yang tidak disebutkan dalam undang-undang menjadi kewenangan pemerintah daerah. Pembagian kewenangan seperti itu menyebabkan ketidakjelasan pembagian kewenangan antar tingkat pemerintahan (Hoessein dan Prasodjo, 2009).

Pemerintah kemudian merevisi PP tersebut, dengan mengeluarkan PP No 38 Tahun 2007 tentang Pembagian Kewenangan antara Pemerintah Pusat, Pemerintah Provinsi dan Pemerintah Kabupaten. PP No 38 tahun 2007 menganut prinsip ultra vires, di mana penyerahan kewenangan kepada pemerintah daerah ditetapkan secara rinci dalam undang-undang. Pembagian urusan pemerintahan di bidang kehutanan terdapat di lampiran $\mathrm{z}$ dari PP tersebut. Menurut PP tersebut pengelolaan hutan lindung ${ }^{1}$ menjadi kewenangan Pemerintah Kabupaten. Desentralisasi pengelolaan hutan lindung meliputi kegiatan: inventarisasi hutan, rehabilitasi hutan dan perlindungan hutan, pemberian perijinan pemanfaatan kawasan hutan, pemungutan hasil hutan bukan kayu yang tidak dilindungi dan tidak termasuk dalam appendix CITES dan pemanfaatan jasa lingkungan skala kabupaten.

\footnotetext{
${ }^{1}$ Hutan Lindung menurut UU No 41 Tahun 1999 adalah kawasan hutan yang mempunyai fungsi pokok sebagai perlindungan sistem penyangga kehidupan untuk mengatur tata air, mencegah banjir, mencegah erosi, mencegah intruisi air laut dan memelihara kesuburan tanah.
} 
Hutan lindung merupakan barang publik. Barang publik adalah barang yang tidak punya tandingan (non rivalry) dalam konsumsi dan/atau manfaatnya tidak bisa dipisahkan (non excludable) (Fauzi, 2004). Hutan lindung bisa memberikan eksternalitas positif maupun negatif, sehingga menimbulkan interdependensi atau ketergantungan antar kabupaten di bagian hulu dan kabupaten di bagian hilir (Kartodihardjo, 2006).

Hutan lindung di beberapa daerah terus terdegradasi. Menurut hasil penghitungan Badan Planologi Kehutanan (2008), luas deforestasi kawasan hutan lindung pada periode tahun 2003 - 2006 adalah 391.000 ha, dengan angka deforestasi tahunan pada kawasan ini adalah $130.300 \mathrm{ha} /$ tahun. Angka deforestasi hutan lindung di Provinsi Jambi 378,2 ha/tahun, sedangkan di Sumatera Barat 72,5 ha/tahun. Keberadaan hutan lindung di kedua provinsi tersebut memberikan kontribusi besar terhadap kesehatan DAS Batanghari. Ada kesenjangan antara kebijakan desentralisasi dan implementasinya. Pemerintah Pusat belum secara jelas menunjukkan komitmennya mendorong otonomi secara bertahap di bidang kehutanan, di sisi lain Pemerintah Kabupaten belum dapat menunjukkan komitmen dan kemampuannya untuk mengurus hutan yang ada di wilayahnya secara baik dan bertanggung jawab (Ngakan et al, 2007).

Ada beberapa pendekatan dalam proses pembuatan kebijakan yaitu : stagist approaches, pluralist-elitist approaches, neo marxist approaches, sub system approaches, policy discources approaches dan institutionalism (Parson, 2008). Proses pembuatan kebijakan yang berjalan saat ini biasa disebut sebagai model linier, model rasional, atau common-sense. Kebijakan disusun berdasarkan sejumlah langkah serial, dimulai dengan merumuskan isu, merumuskan tindakan untuk mengatasi gap, memberi bobot, pelaksanaan kebijakan dan diakhiri sejumlah kegiatan untuk memecahkan masalah (stagist approaches). Menurut aliran ini, implementasi kebijakan dipandang sebagai aktifitas yang terpisah yang dimulai pada saat kebijakan dibuat atau diputuskan. Apabila masalah tidak dapat dipecahkan melalui segenap tindakan yang telah ditetapkan, kesalahan biasanya tidak dialamatkan pada isi kebijakan itu sendiri, melainkan pada pelaksanaannya (IDS, 2006).

Proses pembuatan kebijakan desentralisasi pengelolaan hutan lindung di Indonesia dianalisis dengan policy discourse approach yang mengkaji proses kebijakan dari sudut pandang bahasa dan komunikasi, dengan menganalisis narasi/discourse, aktor/network dan interest-nya (Sutton, 1999; Keely \& Scoones 2003; IDS, 2006). Menurut Dunn (2003), proses pembuatan kebijakan bersifat politis. Makalah ini disusun untuk memahami bagaimana kebijakan pembagian kewenangan antar tingkat pemerintahan dirumuskan dan diimplementasikan. Pertanyaan penelitian dalam kajian ini adalah 1) Bagaimana implementasi dan kinerja Pemerintah Kabupaten dalam pengelolaan hutan lindung? 2) Bagaimana proses pembuatan kebijakan pembagian kewenangan antar tingkat pemerintahan dan 3) Bagaimana pengaruh proses pembuatan kebijakan dengan implementasi kebijakan yang ada? 
Proses Pembuatan Kebijakan Pembagian Kewenangan antara ... . Sulistya EKazwati, Hariadi Kartodifardjo, Hardjanto, Haryatno Dwiprabowo ${ }^{\circ}$ Dodik Ridfo Nurrochmat

\section{METODE PENELITIAN}

\section{A. Kerangka Analisis}

Pendekatan yang digunakan dalam penelitian ini mengacu pada evaluasi proses perumusan kebijakan yang dikembangkan oleh Institute of Development Studies (Sutton, 1999; IDS, 2006). Penetapan masalah serta solusi atas suatu fenomena tertentu melibatkan:

1. Kerangka pikir (discourse/narrative)

Narasi kebijakan adalah sebuah cerita yang memiliki awal, tengah dan akhir, menguraikan peristiwa tertentu yang telah memperoleh status kebijaksanaan konvensional. Contoh tragedy of commons dan krisis kayu bakar di Afrika. Narasi kebijakan mendefinisikan masalah, menjelaskan bagaimana cerita itu muncul ke permukaan dan menunjukkan apa yang perlu dilakukan untuk menghindarkan bencana atau mencapai suatu akhir yang berhasil (bappy ending), apa yang salah dan bagaimana hal tersebut diperbaiki. Para pembuat kebijakan sering mendasarkan keputusan kebijakan pada cerita-cerita yang diuraikan dalam pembangunan narasi. Narasi kebijakan berbeda dengan discourse, yang merujuk kepada nilai-nilai dan cara berpikir yang lebih luas. Sebuah narasi dapat menjadi bagian dari discourse jika menggambarkan cerita tertentu yang sejalan dengan nilai-nilai yang lebih luas dan prioritas.

2. Aktor dan jaringan (actors and network)

Jaringan, koalisi dan aliansi aktor-aktor (individu dan institusi) dengan visi yang sama, keyakinan serupa, kode etik dan kesamaan perilaku sangat penting dalam menyebarkan dan mempertahankan narasi melalui pembujukan publik dan pengaruh seperti jurnal, konferensi, pendidikan atau cara-cara informal. Proses negosiasi dan tawar-menawar di antara kelompok kepentingan yang saling berkompetisi berperan penting dalam pembuatan kebijakan.

3. Politik dan kepentingan (politic and interest)

Proses kebijakan dipengaruhi oleh sejumlah kepentingan kelompok yang menggunakan kekuatan dan kewenangannya atas pembuatan kebijakan. Hal ini mempengaruhi setiap tahapan proses, dari pembentukan agenda, hingga identifikasi alternatif, pembobotan dan pemilihan opsi yang paling menguntungkan serta implementasinya. Kepentingan aktor dalam kebijakan berasal dari instansi pemerintah, organisasi donor dan independent expert.

Memahami policy process datang dari pemahaman ketiga unsur tersebut, pada interseksi dari ketiga perspektif yang tumpang tindih tersebut, seperti terlihat pada Gambar 1. 


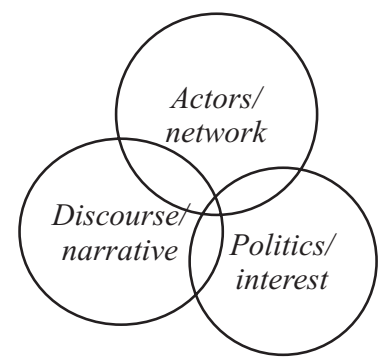

Gambar 1. Evaluasi Proses Pembuatan Kebijakan (IDS, 2006)

Figure1. Evaluation of Policy-Making Process (IDS, 2006)

Kinerja Pemerintah Kabupaten didekati dengan melihat implementasi desentralisasi pengelolaan hutan lindung oleh Pemerintah Kabupaten dan perubahan tutupan hutan lindung sebelum dan setelah desentralisasi (tahun 1990, 2000 dan 2009). Ketidaksesuaian kinerja kebijakan yang diharapkan dan implementasinya dapat membantu mengevaluasi proses pembuatan kebijakan, seberapa jauh masalah telah terselesaikan, kritik terhadap nilai-nilai yang mendasari kebijakan dan membantu penyesuaian kembali perumusan masalah (Dunn, 2003).

\section{A. Waktu dan Lokasi Penelitian}

Penelitian ini dilaksanakan mulai bulan Juni 2009 sampai dengan Agustus 2010. Dasar pemilihan lokasi adalah kabupaten yang mempunyai hutan lindung dan terletak pada satu wilayah Daerah Aliran Sungai (DAS). Kabupaten yang dipilih adalah Kabupaten Tanjung Jabung Timur (mewakili daerah hilir), Kabupaten Sarolangun (mewakili daerah tengah) dan Kabupaten Solok Selatan (mewakili daerah hulu). DAS Batanghari dipilih sebagai lokasi penelitian karena : 1) merupakan salah satu DAS lintas kabupaten dan lintas provinsi, 2) termasuk DAS kritis dan 3) DAS terbesar nomor dua di Indoneisa. Satuan DAS dijadikan pertimbangan karena fungsi hutan lindung terkait dengan tata air dan fungsi lindung lainnya.

\section{B. Pengumpulan Data}

Data proses pembuatan kebijakan dan implementasi desentralisasi pengelolaan hutan lindung dilakukan dengan :1) studi literatur dari data sekunder dan media massa yang terkait dengan isu yang sedang diteliti, 2) wawancara mendalam dengan pejabat di pusat maupun di daerah yang terkait dan LSM dan 3)observasi lapangan. Data pendukung untuk menjelaskan kinerja implementasi desentralisasi pengelolaan hutan lindung tiap kabupaten diambil dari citra landsat 7 $\mathrm{ETM}+$. 
Proses Pembuatan Kebijakan Pembagian Kewenangan antara ... . Sulistya EKazwati, Hariadi Kartodifardjo, Hardjanto, Haryatno Dwiprabowo ${ }^{\circ}$ Dodik Ridfo Nurrochmat

\section{Analisis Data}

Analisis data proses pembuatan kebijakan pembagian kewenangan antar tingkat pemerintahan dilakukan dengan analisis discourse, dengan menggunakan model yang yang dikembangkan oleh Norman Fairclough yang dikenal sebagai model perubahan sosial (social change) (Eriyatno, 2002; 2005 ). Analisis perubahan tutupan lahan hutan lindung sebelum dan setelah desentralisasi (tahun 1990, 2000 dan 2009) dilakukan untuk mendukung data kinerja Pemerintah Kabupaten. Analisis perubahan tutupan lahan mengacu pada klasifikasi lahan yang dilakukan Land Use, Land Use Change and Forestry (LULUCF) Inter Governmental Panel on Climate Change (IPCC) (2006), yang mengklasifikasikan lahan ke dalam 6 kategori yaitu : 1) forest land, 2) grassland, 3) cropland, 4) wetland, 5) settlement dan 6) other land.

\section{HASIL DAN PEMBAHASAN}

\section{A. Kinerja Desentralisasi Pengelolaan Hutan Lindung oleh Pemerintah Kabupaten}

Beberapa kewenangan pengelolaan hutan lindung sudah dijalankan oleh Pemerintah Kabupaten seperti : rehabilitasi, perlindungan dan inventarisasi hutan. Kabupaten Tanjung Jabung Timur melakukan inventarisasi batas hutan, inventarisasi perambahan hutan dan inventarisasi flora dan fauna. Kabupaten Solok Selatan melakukan inventarisasi perambah hutan. Kabupaten Sarolangun tidak melakukan inventarisasi hutan, data yang dipakai selama ini hanya berdasarkan data lama hasil inventarisasi hutan yang dilakukan oleh Dinas Kehutanan Provinsi. Provinsi Jambi pernah melakukan kegiatan inventarisasi flora dan fauna, sedangkan di Provinsi Sumbar pernah melakukan inventarisasi Hasil Hutan Bukan Kayu (manau, rotan, getah, gambir) dan jasa lingkungan.

Kegiatan penanaman di hutan lindung sudah dilakukan oleh Pemerintah Kabupaten, karena Pemerintah Pusat sudah menyediakan skema pendanaan untuk kegiatan penanaman hutan dalam bentuk Dana Bagi Hasil Dana Reboisasi (DBH DR) maupun dana tugas pembantuan (GNRHL, OMOT'2). Kegiatan penanaman di

\footnotetext{
${ }^{2}$ Omot (One Man One Tree) adalah gerakan penanaman pohon seluruh Indonesia minimal satu orang satu pohon untuk lebih meningkatkan kepedulian berbagai pihak akan pentingnya penanaman dan pemeliharaan pohon yang berkelanjutan dalam mengurangi pemanasan global dan untuk mencapai pembangunan Indonesia yang bersih (Permenhut P.20/menhut-II/2009 tentang Panduan Penanaman OMOT). GNRHL (Gerakan Nasional Rehabilitasi Hutan dan Lahan) adalah gerakan moral bangsa untuk menumbuhkan semangat RHL untuk percepatan pemulihan keberadaan dan fungsi hutan serta meningkatkan kesejahteraan masyarakat (Permenhut P.22/Menhut-V/2007 tentang Pedoman Teknis GNRHL).
} 
hutan lindung gambut prosentase hidupnya rendah sekali, karena selalu tergenang air. Kegiatan penanaman di tanah mineral juga sering kali gagal karena kurangnya pemeliharaan. Hama babi menjadi hama utama kegiatan penanaman hutan di kawasan hutan lindung. Kegiatan perlindungan hutan sudah dilakukan oleh beberapa kabupaten, walaupun dengan segala keterbatasan yang ada. Pemerintah Kabupaten terbatas dalam penyediaan sapras dan SDM untuk melakukan pengamanan hutan dan pemadaman kebakaran. Kewenangan yang belum banyak dijalankan adalah ijin pemanfaatan kawasan hutan. Pemerintah Kabupaten Tanjung Jabung Timur secara relatif telah menjalankan $55.56 \%$ kewenangan pengelolaan hutan lindung, Pemerintah Kabupaten Sarolangun 33,33\% dan Pemerintah Kabupaten Solok Selatan 44,44\%.

Tabel 1. Implementasi desentralisasi pengelolaan hutan lindung di Kabupaten Tanjung Jabung Timur, Kabupaten Sarolangun dan Solok Selatan

Table 1. Implementation of protected forest management decentralization in East Tanjung Jabung, Sarolangun and South Solok Regencies

\begin{tabular}{|c|c|c|c|c|}
\hline \multirow{2}{*}{ No. } & \multirow{2}{*}{ Fungsi (Function) } & \multicolumn{3}{|c|}{ Kabupaten (Regency) } \\
\hline & & $\begin{array}{c}\text { Tanjung Jabung } \\
\text { Timur }\end{array}$ & Sarolangun & Solok Selatan \\
\hline \multirow[t]{5}{*}{1.} & Pelaksanaan & & & \\
\hline & $\begin{array}{l}\text { Inventarisasi } \\
\text { hutan }\end{array}$ & $\begin{array}{l}\text { Inventarisasi bat as } \\
\text { hutan, } \\
\text { perambahan, flora } \\
\text { dan fauna }\end{array}$ & - & $\begin{array}{l}\text { Inventarisasi } \\
\text { perambah hutan }\end{array}$ \\
\hline & $\begin{array}{l}\text { Rehabilitasi dan } \\
\text { pemeliharaan } \\
\text { rehabilitasi }\end{array}$ & $\begin{array}{l}\text { Penanaman } \\
\text { jelutung rawa, } \\
\text { pulai, meranti }\end{array}$ & $\begin{array}{l}\text { Penanaman } \\
\text { mahoni, karet, } \\
\text { jelutung darat }\end{array}$ & $\begin{array}{l}\text { Penanaman } \\
\text { karet, mahoni, } \\
\text { durian }\end{array}$ \\
\hline & $\begin{array}{l}\text { Reklamasi hutan } \\
\text { pada areal } \\
\text { bencana alam } \\
\text { skala kabupaten }\end{array}$ & - & - & - \\
\hline & $\begin{array}{l}\text { Perlindungan } \\
\text { dan } \\
\text { pengamananan } \\
\text { hutan }\end{array}$ & $\begin{array}{l}\text { Rekontruksi batas } \\
\text { kawasan, patroli, } \\
\text { pemadaman } \\
\text { kebakaran, } \\
\text { penyuluhan }\end{array}$ & $\begin{array}{l}\text { Patroli, } \\
\text { pemadaman } \\
\text { kebakaran, } \\
\text { penyuluhan }\end{array}$ & $\begin{array}{l}\text { Patroli, } \\
\text { rekontruksi batas } \\
\text { kawasan, } \\
\text { pengangkatan } \\
\text { polisi nagari, } \\
\text { pemadaman } \\
\text { kebakaran, } \\
\text { penyuluhan }\end{array}$ \\
\hline
\end{tabular}


Proses Pembuatan Kebijakan Pembagian Kewenangan antara ... Sulistya EKawati, Hariadi Kartodifardjo, Hardjanto, Haryatno Dwiprabowo ${ }^{\circ}$ Dodik Ridho Nurrochmat

Tabel 1. Lanjutan

Table 1. Continued

\begin{tabular}{|c|c|c|c|c|}
\hline \multirow[b]{2}{*}{ No. } & \multirow{2}{*}{ Fungsi (Function) } & \multicolumn{3}{|c|}{ Kabupaten (Regency) } \\
\hline & & $\begin{array}{c}\text { Tanjung Jabung } \\
\text { Timur }\end{array}$ & Sarolangun & Solok Selatan \\
\hline 2. & $\begin{array}{l}\text { Pertimbangan teknis } \\
\text { penyusunan } \\
\text { rancangan bangun, } \\
\text { pengusulan dan } \\
\text { perencanaan } \mathrm{KPH} \\
\end{array}$ & $\begin{array}{l}\text { Sudah ada } \\
\text { penetapan wilayah } \\
\text { KPHP unit XIV } \\
\text { Tanjabtim }^{3}\end{array}$ & $\begin{array}{l}\text { Sudah ada } \\
\text { penetapan wilayah } \\
\text { KPHP Unit VII } \\
\text { Sarolangun }{ }^{4}\end{array}$ & $\begin{array}{l}\text { Sudah ada } \\
\text { penetapan KPHL } \\
\text { Unit VII }{ }^{5}\end{array}$ \\
\hline 3. & $\begin{array}{l}\text { Pemberian ijin } \\
\text { Pemberian } \\
\text { perijinan } \\
\text { pemanfaatan } \\
\text { kawasan hutan }\end{array}$ & $\begin{array}{l}\text { Belum memproses } \\
\text { perijinan } \\
\text { pemanfaaatan } \\
\text { kawasan }\end{array}$ & $\begin{array}{l}\text { Belum memproses } \\
\text { perijinan } \\
\text { pemanfaaatan } \\
\text { kawasan }\end{array}$ & $\begin{array}{l}\text { Belum } \\
\text { memproses } \\
\text { perijinan } \\
\text { pemanfaaatan } \\
\text { kawasan }\end{array}$ \\
\hline & $\begin{array}{l}\text { Pemungutan } \\
\text { HHBK yang } \\
\text { tidak dilindungi } \\
\text { dan bukan } \\
\text { masuk daftar } \\
\text { CITES }\end{array}$ & $\begin{array}{l}\text { Pernah ada ijin } \\
\text { pemungutan } \\
\text { rotan, tetapi } \\
\text { sekarang sudah } \\
\text { tidak ada lagi }\end{array}$ & $\begin{array}{l}\text { Pernah ada ijin } \\
\text { pemungutan } \\
\text { rotan, tetapi } \\
\text { sekarang sudah } \\
\text { tidak ada lagi }\end{array}$ & $\begin{array}{l}\text { Pernah ada ijin } \\
\text { pemungutan } \\
\text { rotan, tetapi } \\
\text { sekarang sudah } \\
\text { tidak ada lagi }\end{array}$ \\
\hline & $\begin{array}{l}\text { Pemanfaatan jasa } \\
\text { lingkungan }\end{array}$ & - & - & - \\
\hline 4. & Pemantauan & & & \\
\hline & $\begin{array}{l}\text { Pemantauan } \\
\text { pelaksanaan } \\
\text { reklamasi hutan }\end{array}$ & $\begin{array}{l}\text { Sebagai tim } \\
\text { pemantau } \\
\text { pelaksanaan } \\
\text { reklamasi PT } \\
\text { Petro China }\end{array}$ & - & - \\
\hline
\end{tabular}

Keterangan(Remark) : - = kewenangan belum dijalankan (authority has not been executed) Sumber (Source) : analisis data primer (primary data analysis)

Hasil analisis perubahan tutupan lahan menunjukkan bahwa Kabupaten Sarolangun mempunyai laju deforestasi paling tinggi, kemudian diikuti Kabupaten Tanjung Jabung Timur dan Kabupaten Solok Selatan. Perubahan tutupan lahan disajikan pada Gambar 2, Gambar 3, Gambar 4 dan Gambar 5.

\footnotetext{
${ }^{3}$ Berdasarkan SK .77/Menhut- II/2010 tanggal 10 Februari 2010

${ }^{4}$ Berdasarkan SK .77/Menhut-II/2010 tanggal 10 Februari 2010

${ }^{5}$ Berdasarkan SK .798/Menhut-II/2010 tanggal 7 Desember 2009
} 


\begin{tabular}{|c|c|c|c|}
\hline \multirow{2}{*}{$\begin{array}{l}\text { Kabu- } \\
\text { paten/ } \\
\text { Regency }\end{array}$} & \multicolumn{3}{|c|}{ Tahun/Year } \\
\hline & 1990 & 2000 & 2009 \\
\hline $\begin{array}{c}\text { Tanjung } \\
\text { Jabung } \\
\text { Timur }\end{array}$ & & $=$ & $=$ \\
\hline
\end{tabular}

Gambar 2. Perubahan tutupan lahan di hutan lindung Kabupaten Tanjung Jabung Timur pada tahun 1990, 2000 dan 2009

Figure 2. Land cover change on protected forest of East Tanjung Jabung Regency in the year 1990, 2000 and 2009

\begin{tabular}{|c|c|c|c|}
\hline \multirow{2}{*}{$\begin{array}{c}\text { Kabu- } \\
\text { paten/ } \\
\text { Regency }\end{array}$} & \multicolumn{3}{|c|}{ Tahun/Year } \\
\cline { 2 - 4 } & 1990 & 2000 & 2009 \\
\hline $\begin{array}{c}\text { Sarola- } \\
\text { ngun }\end{array}$ & & & \\
\hline
\end{tabular}

Gambar 3. Perubahan tutupan lahan di hutan lindung Kabupaten Sarolangun pada tahun 1990, 2000 dan 2009

Figure 3. Land cover change on protected forest of Sarolangun Regency in the year 1990,2000 and 2009 
Proses Pembuatan Kebijakan Pembagian Kewenangan antara ... Sulistya Ekawati, Hariadi Kartodifardjo, Hardjanto, Haryatno Dwiprabowo Dodik Ridho Nurrochmat

\begin{tabular}{|c|c|c|c|}
\hline $\begin{array}{c}\text { Kabu- } \\
\text { paten/ } \\
\text { Regency }\end{array}$ & 1990 & \multicolumn{3}{|c|}{ Tahun/Year } \\
\hline & & 2000 & 2009 \\
Solok & & &
\end{tabular}

Gambar4. Perubahan tutupan lahan di hutan lindung Kabupaten Solok Selatan pada tahun 1990, 2000 dan 2009

Figure 4. Land cover change on protected forest of South Solok Regency in the year 1990,2000 and 2009

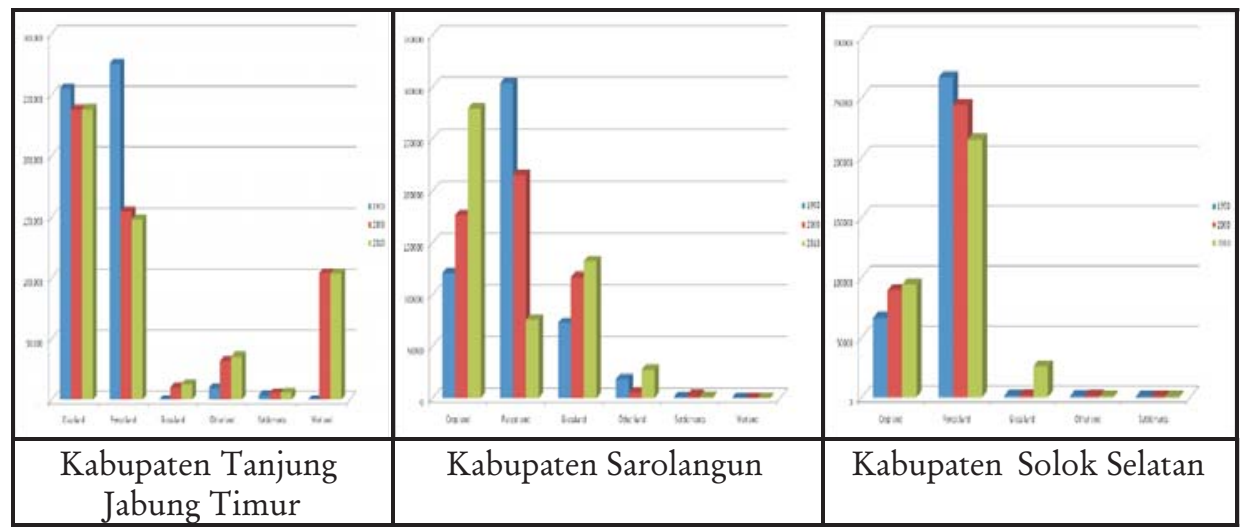

Gambar 5. Perubahan luas tutupan lahan di hutan lindung pada masing-masing kabupaten

Figure 5. Land coverchange in protected forest area in each regency 


\section{B. Kronologi Proses Pembuatan Kebijakan Pembagian Kewenangan Pengelolaan Hutan}

Kebijakan pembagian kewenangan pengelolaan hutan di atur dalam PP No 38 Tahun 2007 tentang Pembagian Kewenangan antara Pemerintah, Pemerintah Provinsi dan Pemerintah Kabupaten/Kota. Proses lahirnya PP tersebut beserta lampirannya sangat terkait dengan perundang-undangan yang ada di atasnya yaitu UU No 32 tahun 2004 tentang Pemerintah Daerah. UU ini merupakan hasil revisi UU No 22 Tahun 1999. Polemik untuk merevisi UU No 22 Tahun 1999 berlangsung seru dan sengit di antara tiga kelompok yang berperan, yaitu: 1) kelompok prorevisi (terutama Kementerian Dalam Negeri dan pelaku bisnis), 2) kelompok kontra-revisi (Asosiasi Pemerintah Daerah), dan 3) kelompok "pro dengan reserve", yakni setuju revisi, tetapi didahului evaluasi komprehensif (didukung oleh sebagian pegiat/peneliti otonomi daerah). Dalam perkembangannya, terjadi kesepahaman semua pihak bahwa revisi UU tersebut merupakan keniscayaan, dengan alasan banyaknya substansi (pasal) yang dinilai salah/lemah atau yang bersifat multitafsir yang menyebabkan kesimpangsiuran dalam praktik dan munculnya tuntutan baru (seperti reformasi elektoral bagi pemilihan kepala daerah langsung, pembaruan arsitektur fiskal yang lebih berimbang antar daerah) ${ }^{6}$.

Forum Asosiasi Pemerintahan Daerah menyatakan pandangannya untuk menunda rencana revisi UU 22/1999 setidaknya setelah rangkaian Pemilihan Umum 2004 selesai $^{7}$. Peta polemik selanjutnya bergeser kepada pilihan isu apa yang perlu direvisi. Pada saat itu muncul bermacam-macam draf RUU (versi LIPI, Koalisi LSM, Asosiasi Daerah, DPR dan Kementerian Dalam Negeri, Kementrian Pendayagunaan Aparatur Negara), maupun sekadar pokok-pokok pikiran dalam bentuk kertas kerja atau naskah akademik. Berdasarkan Peraturan Tata Tertib DPR RI pasal $100^{\circ}$, maka yang menjadi acuan utama pembahasan adalah RUU dari DPR, sementara draft yang lain, (versi Kementerian Dalam Negeri, LIPI, Koalisis LSM, Asosiasi Daerah dan sebagainya) hanya akan menjadi sandingan yang akan melengkapi Daftar Isian Masalah (DIM). Draft dari DPR masih banyak kekurangannya dari segi jangkauan dan bobot pengaturan, bila dibandingkan

\footnotetext{
${ }^{6}$ Robert Endi Jaweng (Peneliti KPPOD). Ikwal Revisi UU No 22 Tahun 2004. Kompas, 20 Desember 2004. Http://www2.kompas.com. diakses 7 Juni 2009

${ }^{7}$ Penyataan sikap Forum Pemerintah Daerah Seluruh Indonesia terhadap penyempurnaan UU No 22 Tahun 1999 tentang Pemerintah daerah. Diakses dari www.parlement.net. diakses 6Juli 2009

${ }^{8}$ Pasal 100 Peraturan Tata Tertib DPR RI berbunyi : "Apabila ada 2 (dua) rancangan undang-undang yang diajukan mengenai hal yang sama dalam satu masa sidang, yang dibicarakan adalah rancangan undang-undang dari DPR, sedangkan rancangan undang-undang yang diajukan oleh Presiden digunakan sebagai bahan untuk dipersandingkan”.
} 
Proses Pembuatan Kebijakan Pembagian Kewenangan antara ... . Sulistya EKawati, Hariadi Kartodihardjo, Hardjanto, Haryatno Dwiprabowo ${ }^{\star}$ DodiK Ridfo Nurrochmat

dengan draft versi lain, terutama dari Kementerian Dalam Negeri dan LIPI'. Secara umum disimpulkan bahwa proses revisi UU No 22 Tahun 1999 tidak jelas, karena tidak transparan, tidak aspiratif dan mengabaikan keterlibatan stakeholder ${ }^{10}$.

Setelah proses revisi UU No 22 Tahun 1999 selesai, pada tanggal 29 September 2004 disyahkan UU penggantinya, yaitu UU No 32 tahun 2004. Selanjutnya juga dilakukan revisi terhadap peraturan perundangan yang merupakan penjabaran UU tersebut yaitu revisi PP 25 tahun 2000, maka disusunlah RPP tentang Pembagian Urusan Pemerintahan antara Pemerintah, Pemerintah Daerah Provinsi dan Pemerintah Daerah Kabupaten/Kota, yang membagi secara jelas kewenangan ketiga tingkat pemerintahan tersebut. Untuk melengkapi RPP tersebut dikeluarkanlah surat edaran dari Menteri Dalam Negeri agar masingmasing sektor menyusun draft pembagian kewenangan, termasuk di antaranya sektor kehutanan. Kementerian Dalam Negeri memberi tiga kriteria dalam pembagian urusan antar tingkat pemerintahan yaitu : eksternalitas (jangkauan dampak), akuntabilitas (kedekatan dengan dampak) dan efisiensi (daya guna tertinggi). Tarik-menarik kewenangan ini membuat penyusunan PP No 38/2007 memakan waktu lama, hampir dua tahun, karena ada beberapa urusan yang masih bermasalah, yaitu kewenangan di bidang pertanahan, perhubungan laut, ijin pertambangan dan kewenangan Badan Koordinasi Penanaman Modal (BKPM) ${ }^{11}$.

Pembagian urusan antar tingkat pemerintahan di bidang kehutanan dilakukan oleh Kementerian Kehutanan beserta seluruh jajaran eselon satunya untuk menyusun draft pembagian kewenangan sesuai dengan tugas pokok dan fungsi masing-masing. Secara umum draft tersebut kemudian diverifikasi oleh Biro Hukum, selanjutnya didiskusikan dengan beberapa perwakilan dari beberapa provinsi dan kabupaten. Sosialisasi pertama dilakukan "Workshop Muatan Materi Rancangan Peraturan Pemerintah (RPP) tentang Pembagian Urusan Pemerintahan Bidang Kelautan, Perikanan dan Kehutanan di Pekanbaru, Riau pada tanggal 27 Juli 2005. Workshop tersebut diikuti para gubernur di Indonesia, Ketua Asosiasi Pemerintah Provinsi Seluruh Indonesia (APPSI), pejabat di Dinas Perikanan, Kelautan dan Kehutanan dari seluruh Indonesia. Hasil workshop di Pekanbaru

\footnotetext{
${ }^{9}$ Fahmi Wibawa (Manajer Program Desentralisasi dan Otonomi Daerah pada Kemitraan /Partnership for Governance Reform in Indonesia). Mengembalikan Otonomi kepada Rakyat. Kompas, 12 Oktober 2004. http://www2.kompas.com. diakses 7 Juli 2009 dan Jaweng RE. op. cit.

${ }^{10}$ Yayasan Penguatan Partisipasi dan Inisiatif dan Kemitraan Masyarakat Indonesia (YAPPIKA), Partnership kemitraan dan FLEGT. Hasil Laporan Konteks Historis Perubahan UU Pemerintah daerah (UU No 22/1999 menjadi UU No.32/2004) . 2006. hal 21-23. http://yappika.or.id. Diakses 25 Oktober 2010

${ }^{11}$ Susieberindra. Mencari Arah Desentralisasi. Resource Center for Popular Participation. Kompas, 1 Juli 2010. http://desentralisasi.net. 2010. diakses 17 Mei 2010
} 
tersebut adalah draft muatan materi pembagian urusan pemerintahan bidang kehutanan yang masih belum disepakatinya 9 issue pending antara Pemerintah dan Pemerintah Daerah. Pertemuan selanjutnya diadakan tanggal 26 Agustus 2005 di Jakarta, dengan dihadiri wakil-wakil Kementerian Kehutanan, Kementerian Dalam Negeri, Dinas Kehutanan Provinsi dan Dinas Kehutanan Kabupaten/Kota. Pada pembahasan tersebut tercapai kesepakatan atas keseluruhan issue pending, dengan demikian draf muatan pembagian urusan pemerintahan bidang kehutanan antara pemerintah Pusat, Pemerintah Provinsi dan Kabupaten/Kota dinyatakan final. Proses selanjutnya adalah sinkronisasi dan harmonisasi pembagian urusan antar sektor $^{12}$. Pembahasan kebijakan pembagian kewenangan antar tingkat pemerintahan di bidang kehutanan dilakukan dua kali, dilihat dari keterwakilan stakeholder yang diundang, workshop dilakukan dengan melibatkan stakeholder yang sangat terbatas.

\section{Proses Pembuatan Kebijakan Pembagian Kewenangan Antar Tingkat Pemerintahan}

Dalam proses pembuatan kebijakan pembagian kewenangan antar tingkat pemerintahan di Indonesia, ada tiga diskursus yang berkembang, yaitu : demokratis, ekonomis dan gabungan antara demokratis dan ekonomis. Koalisi diskursus menciptakan kompromi (jalan tengah). Overview tiga diskursus dalam pembagian kewenangan antar tingkat pemerintahan dapat dilihat pada Tabel 2.

\footnotetext{
${ }^{12}$ Wawancara dengan Suhaeri, Kepala Bagian Kelembagaan, Biro Hukum dan Organisasi, Kementrian Kehutanan, tanggal 3 November 2010
} 
Proses Pembuatan Kebijakan Pembagian Kewenangan antara ... Sulistya EKawati, Hariadi Kartodifardjo, Hardjanto, Haryatno Dwiprabowo ${ }^{\circ}$ Dodik Ridho Nurrochmat

Tabel 2. Overviewe tiga diskursus dalam pembagian kewenangan antar tingkat pemerintahan ${ }^{13}$

Table 2. Overview of three discourses in the division of authority among the levels of goverment

\begin{tabular}{|c|c|c|c|}
\hline & $\begin{array}{l}\text { Diskursus democra-tis } \\
\text { (Democratist discourse) }\end{array}$ & $\begin{array}{l}\text { Diskursus eko-nomis } \\
\text { (Economist discourse) }\end{array}$ & $\begin{array}{l}\text { Diskursus Demokratis- } \\
\text { Ekonomis (Democratist- } \\
\text { Economist Discourse) }\end{array}$ \\
\hline $\begin{array}{l}\text { Tipe pendukung } \\
\text { (organisasi, disiplin) } \\
\text { (type proponent } \\
\text { (organization/ } \\
\text { disciplines)) }\end{array}$ & $\begin{array}{l}\text { Forum Asosiasi } \\
\text { Pemerintah Daerah } \\
\text { dan Pakar desentralisasi }\end{array}$ & $\begin{array}{l}\text { - Pendukung } \\
\text { sentralisasi } \\
\text { (pebisnis, peng- } \\
\text { usaha) } \\
\text { - APPSI, World } \\
\text { Bank }\end{array}$ & $\begin{array}{l}\text { DPR dan Departemen } \\
\text { Dalam Negeri }\end{array}$ \\
\hline $\begin{array}{l}\text { Argumen sentral } \\
\text { dari story line } \\
\text { (central argument of } \\
\text { the story lines) }\end{array}$ & $\begin{array}{l}\text { - Eksternalitas : } \\
\text { tingkat pemerin- } \\
\text { tahan yang terkena } \\
\text { dampak adalah yang } \\
\text { berwenang mengurus } \\
\text { - Akuntabilitas : } \\
\text { tingkat pemerin- } \\
\text { tahan yang paling } \\
\text { dekat dengan dam- } \\
\text { pak yang ber-wenang } \\
\text { mengurus } \\
\end{array}$ & $\begin{array}{l}\text { Efisiensi: } \\
\text { berjalannya otonomi } \\
\text { harus efisien tidak } \\
\text { boleh high cost } \\
\text { enonomy. }\end{array}$ & $\begin{array}{l}\text { Prinsipnya demokrasi } \\
\text { (eksternalitas, akuntabilitas) } \\
\text { dan prinsip ekonomi } \\
\text { (efisiensi) }\end{array}$ \\
\hline $\begin{array}{l}\text { Prioritas/misi } \\
\text { (priorities/mission) }\end{array}$ & $\begin{array}{l}\text { Membangun } \\
\text { demokrasi dalam } \\
\text { penyelengaraan } \\
\text { pemerintahan }\end{array}$ & $\begin{array}{l}\text { Penyediakan } \\
\text { pelayanan publik } \\
\text { secara efektif, efisien } \\
\text { dan ekonomis } \\
\end{array}$ & $\begin{array}{l}\text { Mewujudkan pemerintahan } \\
\text { yang demokratis dan } \\
\text { efisien }\end{array}$ \\
\hline $\begin{array}{l}\text { Posisi pendukung } \\
\text { (representasi diri) } \\
\text { (proponents (self } \\
\text { representation)) }\end{array}$ & $\begin{array}{l}\text { - Partisipasi } \\
\text { masyarakat dalam } \\
\text { pemerintahan } \\
\text { - Kesetaraan antar } \\
\text { warga negara } \\
\text { - Akuntabilitas kepada } \\
\text { masyara-kat lebih } \\
\text { terjamin } \\
\end{array}$ & $\begin{array}{l}\text { Efisiensi } \\
\text { penyelenggaraan } \\
\text { urusan penting } \\
\text { dalam era globalisasi }\end{array}$ & $\begin{array}{l}\text { Desentralisasi di Indonesia } \\
\text { berbeda dengan } \\
\text { desentralisasi di negara lain }\end{array}$ \\
\hline $\begin{array}{l}\text { Posisi lawan } \\
\text { (representatif } \\
\text { lainnya) opponents } \\
\text { (other representation) }\end{array}$ & $\begin{array}{l}\text { Prinsip ekonomi } \\
\text { dianggap tidak } \\
\text { demokratis }\end{array}$ & $\begin{array}{l}\text { Prinsip demokrasi } \\
\text { dianggap tidak } \\
\text { efisien }\end{array}$ & $\begin{array}{l}\text { Prinsip demokrasi } \\
\text { dianggap tidak efisien } \\
\text { - Prinsip efisiensi dianggap } \\
\text { tidak demokratis } \\
\end{array}$ \\
\hline
\end{tabular}

Tabel diadopsi dari Wittmer and Birner, 2003 (the table was adopted from Wittmer and Birner, 2003) Sumber (source) : analisis data primer (primary data analysis)

${ }^{13}$ Dianalisis dari 56 teks, terdiri dari 33 teks makalah populer (16 teks dari media cetak dan 17 teks dari website institusi) dan 23 teks makalah ilmiah (10 teks paper ilmiah, 5 teks jurnal ilmiah dan 8 teks berupa buku). 


\section{Diskursus demokrasi}

Story line $e^{14}$ dari diskursus demokrasi adalah narasi kebijakan ekternalitas dan akuntabilitas. Menurut Direktur Otonomi Daerah, Made Suwandi ${ }^{15}$, sebenarnya kriteria umum yang dipakai dalam pembagian kewenangan adalah eksternalitas (spill over) saja. Konsep eksternalitas dikembangkan dari subsidiarity principle. Subsidiarity principles menyatakan bahwa tingkat pemerintahan yang paling bawah adalah yang berwenang mengurus. Story line eksternalitas adalah pendekatan dalam pembagian urusan pemerintahan dengan mempertimbangkan dampak/akibat yang ditimbulkan dalam penyelenggaraan urusan pemerintahan tersebut. Apabila dampak yang ditimbulkan bersifat lokal, maka urusan pemerintahan tersebut menjadi kewenangan kabupaten/kota, apabila berdampak regional menjadi kewenangan provinsi, dan apabila berdampak nasional menjadi kewenangan Pemerintah Pusat ${ }^{16}$. Berdasarkan kondisi empirik di Indonesia, dimana banyak urusan diotonomikan ke kabupaten (contoh : hutan dan laut), sehingga ada anomali untuk kasus di Indonesia.

Kriteria eksternalitas ditambah kriteria akuntabilitas. Kriteria akuntabilitas dipilih karena jika kriteria eksternalitas saja yang dipakai, maka untuk urusan cost center tidak ada yang mau mengurus. Kriteria akuntabilitas adalah pendekatan dalam pembagian urusan pemerintahan dengan pertimbangan bahwa tingkat pemerintahan yang menangani sesuatu bagian urusan adalah tingkat pemerintahan yang lebih langsung/dekat dengan dampak/akibat dari urusan yang ditangani tersebut. Penyerahan urusan tersebut akan menciptakan akuntabilitas Pemerintah Daerah kepada masyarakat. Ini berarti, makin dekat unit pemerintahan yang memberikan pelayanan kepada masyarakat akan makin mendukung akuntabilitas. Dengan demikian akuntabilitas penyelenggaraan bagian urusan pemerintahan tersebut kepada masyarakat akan lebih terjamin ${ }^{17}$. Pendukung diskursus demokratis adalah Forum Asosiasi Pemerintah Daerah dan pakar desentralisasi.

\section{Diskursus ekonomi}

Story line dari diskursus ekonomi adalah narasi kebijakan efisiensi. Story line dari narasi kebijakan efisiensi adalah sebagai trade off dari dua kriteria sebelumnya. Memasuki era globalisasi tidak boleh ada kegiatan high cost. Economy of scale bisa tercapai bila catchment area optimal. Narasi kebijakan efisiensi adalah pendekatan

\footnotetext{
${ }^{14}$ Hajer (1995) dalam Bitner and Wittmer (2003) mendefinisikan story-line sebagai semacam narasi pendek generatif dari realitas sosial melalui unsur-unsur dari berbagai domain yang digabungkan dan menyediakan aktor dengan satu set simbolis referensi yang menunjukkan pemahaman umum

${ }^{15}$ Wawancara dengan Direktur Otonomi Daerah, Departemen Dalam Negeri, Made Suwandi, tanggal 22 Januari 2010, Jakarta.

${ }^{16}$ Sekretariat DPR. Draft Revisi UU No 22 Tahun 1999, dikeluarkan pada tanggal 29 September 2004.

${ }^{17}$ Sekretariat DPR. Ibid.
} 
dalam pembagian urusan pemerintahan dengan mempertimbangkan tersedianya sumber daya (personil, dana, dan peralatan) untuk mendapatkan ketepatan, kepastian, dan kecepatan hasil yang harus dicapai dalam penyelenggaraan bagian urusan. Artinya apabila suatu bagian urusan dalam penanganannya dipastikan akan lebih berdaya guna dan berhasil guna dilaksanakan oleh Pemerintah Provinsi dan/atau Pemerintah Kabupaten/Kota dibandingkan apabila ditangani oleh Pemerintah maka bagian urusan tersebut diserahkan kepada Pemerintah Provinsi dan/atau Kabupaten/Kota. Sebaliknya apabila suatu bagian urusan akan lebih berdaya guna dan berhasil guna bila ditangani oleh Pemerintah maka bagian urusan tersebut tetap ditangani oleh Pemerintah. Untuk itu pembagian bagian urusan harus disesuaikan dengan memperhatikan ruang lingkup wilayah beroperasinya bagian urusan pemerintahan tersebut. Ukuran daya guna dan hasil guna tersebut dilihat dari besarnya manfaat yang dirasakan oleh masyarakat dan besar kecilnya risiko yang harus dihadapi ${ }^{18}$. Pendukung dari diskursus ekonomi adalah pendukung sentralisasi (pebisnis dan pengusaha), APPSI dan World Bank.

\section{Koalisi dua diskursus}

Pendukung penggabungan dua diskursus tersebut adalah DPR (terutama dari partai-partai besar) dan Kementerian Dalam Negeri. Terjadi dominasi yang saling berganti antara Kementerian Dalam Negeri dan DPR. DPR lebih dominan dalam pembahasan mengenai Pilkada, sementara Kemdagri lebih dominan untuk masalah pemerintahan umum. Kementerian Dalam Negeri dan DPR mencari jalan tengah (zero sum game) antara prinsip demokratis (eksternalitas, akuntabilitas) dan prinsip ekonomis (efisiensi). Kedua diskursus tersebut digabungkan untuk mencari keseimbangan, meskipun story line diskursus demokrasi dan ekonomi awalnya difokuskan pada masalah yang berbeda.

\section{Implementasi Tiga Narasi Kebijakan dalam Proses Pembagian Kewenangan Bidang Kehutanan}

Berdasarkan tiga kriteria di atas, Menteri Dalam Negeri mengeluarkan surat edaran agar masing-masing sektor menyusun draft pembagian kewenangan, termasuk diantaranya sektor kehutanan. Berdasarkan pada tiga narasi kebijakan tersebut, Kementerian Kehutanan menyusun pembagian kewenangan antar tingkat pemerintahan di bidang kehutanan. Kegiatan apa saja yang didesentralisasikan tergantung Kementerian masing-masing. Tiap-tiap kementerian memiliki sense,

\footnotetext{
${ }_{18}$ Paparan Direktur Otonomi Daerah tentang PP 38 Tahun 2007 tentang Pembagian Urusan Pemerintahan antara Pemerintah, Pemerintah Provinsi dan Pemerintah Daerah Kabupaten/Kota. Dalam Koridor UU No 32 Tahun 2004 tentang Pemerintah Daerah dan Sekretariat DPR
} 
kriteria mana yang harus didahulukan ${ }^{19}$. Sebagai contoh untuk urusan pemerintahan inventarisasi hutan lindung, maka akan lebih efektif jika dilaksanakan oleh Pemerintah Kabupaten, tetapi untuk urusan pengukuhan kawasan dilakukan oleh Pemerintah Pusat, dengan pertimbangan eksternalitas/dampak jika urusan tersebut diserahkan kepada Pemerintah Daerah. Penyelenggaraan urusan pengukuhan berdampak global dan strategis sehingga dipertahankan menjadi kewenangan Pemerintah Pusat ${ }^{20}$.

Berdasarkan tiga kriteria tersebut, pembagian kewenangan antar tingkat pemerintahan yang terkait dengan pengelolaan hutan lindung adalah sebagai berikut ${ }^{21}$.

1. Pemerintah Pusat berwenang membuat norma, standar, pedoman dan kriteria (NSPK), kebijakan, law enforcement, fasilitasi aturan main di daerah dan mengurus hutan lindung lintas provinsi.

2. Pemerintah Provinsi berwenang mengatur dan mengurus hutan lindung lintas kabupaten sesuai NSPK yang dibuat Pemerintah Pusat

3. Pemerintah Kabupaten/Kota berwenang mengatur dan mengurus hutan lindung skala kabupaten/kota sesuai NSPK yang dibuat Pemerintah Pusat.

Penggunaan tiga kriteria dalam pratiknya sangat sulit implementasikan. Penerapan kriteria eksternalitas tidak sederhana karena pemerintah daerah sering kurang memperhatikan dampak dari kegiatannya terhadap pihak lain di luar yurisdiksinya. Kriteria efisiensi dalam penyelenggaraan urusan selalu mengarah pada skala ekonomi, sehingga urusan cenderung diserahkan kepada pemerintah yang lebih tinggi. Sementara itu kriteria akuntabilitas, cenderung menunjuk pada tingkat pemerintahan yang lebih dekat dengan masyarakat. Pembagian kewenangan juga belum mempertimbangkan kapabilitas daerah, yang memungkinkan pemerintah dan daerah dapat secara optimal menjalankan kewenangannya ${ }^{22}$.

Beberapa hasil penelitian juga menunjukkan kebijakan pembagian kewenangan antara pusat-provinsi-kabupaten di Indonesia menunjukkan kuatnya penyeragaman (uniformity), sehingga menimbulkan konflik di tingkat lokal. Kebijakan tersebut tidak memperhatikan keragaman, potensi dan kesiapan daerah ${ }^{23}$.

\footnotetext{
${ }^{19}$ Wawancara dengan Staf Ahli Menteri Bidang Pemerintahan, Made Suwandi, 13 Januari 2011

${ }^{20}$ Wawancara dengan Suhaeri. Kepala Bagian kelembagaan Biro Hukum dan Organisasi, Kementrian kehutanan, tanggal 3 November 2010

${ }^{21}$ Wawancara dengan Direktur Otonomi Daerah, Made Suwandi, 22 Januari 2010, Jakarta

${ }^{22}$ Draf Naskah Akademik Revisi UU No 32 Tahun 2004 tentang Pemerintah daerah, 2009. GTZ kerjasama dengan Departemen dalam Negeri.

${ }^{23}$ Hasil penelitian Yayasan Harkat Bangsa dalam Buku Menata Kewenangan Pusat Daerah yang Aplikatif-Demokratis yang ditulis oleh Zuhro dkk, 2006. LIPI Press.
} 
Proses Pembuatan Kebijakan Pembagian Kewenangan antara ... . Sulistya EKawati, Hariadi Kartodihardjo, Hardjanto, Haryatno Dwiprabowo ${ }^{\star}$ DodiK Ridfo N Nurrochmat

Hasil penelitian ini juga menunjukkan bahwa Pemerintah Kabupaten belum menjalankan semua kewenangan pengelolaan hutan lindung yang didesentralisasikan oleh Pemerintah Pusat. Ketiga Pemerintah Kabupaten secara relatif baru menjalankan sebagian $(33,33-55,56 \%)$ kewenangan pengelolaan hutan lindung. Implikasi dari kondisi tersebut adalah terus terdegradasinya hutan lindung di wilayah tersebut. Perubahan tutupan hutan menjadi non hutan sebelum dan setelah desentralisasi mengindikasikan bahwa kebijakan tersebut tidak efektif. Tidak efektifnya sebuah kebijakan terkait dengan proses pembuatan kebijakan pembagian kewenangan antar tingkat pemerintahan.

Proses pembuatan kebijakan pembagian kewenangan antar tingkat pemerintahan berjalan cukup lama, kurang transparant, kurang aspiratif dan hanya melibatkan sedikit stakeholder. Narasi kebijakan yang digunakan (eksternalitas, akuntabilitas dan efesiensi) ternyata tidak menyelesaikan permasalahan yang terjadi di lapangan. Permasalahan kapabilitas daerah yang sering menjadi kendala dalam implementasi desentralisasi, tidak dijadikan sebagai salah satu kriteria dalam kebijakan pembagian kewenangan.

\section{KESIMPULAN DAN SARAN}

\section{A. Kesimpulan}

1. Terdapat dua diskursus yang berkembang dalam proses pembagian kewenangan yaitu diskursus demokrasi (dengan argumen sentral eksternalitas dan akuntabilitas, didukung oleh Forum Asosiasi Pemerintah Daerah dan pakar desentralisasi) dan diskursus ekonomi (dengan argumen sentral efisiensi, didukung oleh pebisnis, APPSI dan World Bank). Kelompok DPR dan Kementerian Dalam Negeri memiliki kapasitas (leverage) yang besar dan dominan, selanjutnya menggabungkan dua diskursus tersebut.

2. Terdapat kesenjangan antara kebijakan dan implementasinya di lapangan. Kesenjangan tersebut terjadi karena policy narrative dan discourse yang telah menjadi conventional wisdom dan tidak sejalan dengan masalah yang dihadapi, sehingga kebijakan yang diambil tidak menyelesaikan permasalahan yang dihadapi dalam desentralisasi pengelolaan hutan lindung

3. Kinerja pengelolaan hutan lindung ditentukan oleh perumusan kebijakan dan implementasi kebijakan di lapangan. Perubahan tutupan hutan menjadi non hutan menunjukkan bahwa kebijakan yang ada terbukti belum efektif. 


\section{B. Saran}

1. Selama ini pembaruan kebijakan bersumber dari narasi kebijakan dan diskursus yang telah melekat dalam keyakinan para pengambil keputusan. Proses pembuatan kebijakan desentralisasi pembagian kewenangan perlu dilakukan secara terbuka, agar kebijakan yang dihasilkan lebih efektif.

2. Pemahaman terhadap proses pembuatan dan implementasi kebijakan akan memberikan kritik terhadap nilai-nilai yang mendasari kebijakan dan membantu merumuskan kembali masalah untuk perbaikan kebijakan ke depan.

\section{DAFTAR PUSTAKA}

Badan Planologi Kehutanan. 2008. Penghitungan Deforestasi Indonesia Tahun 2008. Jakarta. Pusat Inventarisasi dan Perpetaan Hutan.

Dunn W. 2003. Pengantar Analisis Kebijakan Publik. Wibawa S, dkk (penerjemah). Terjemahan dari : Public Polycy Analysis. An Introduction. Yogyakarta. Gadjahmada University Press.

Eriyatno. 2002. Analisis Framing : Konstruksi, Ideologi, dan Politik Media. Yogyakarta. LKIS.

.2005. Analisis Wacana:Pengantar Analisis Teks Media. Yogyakarta. LKIS.

Fauzi A. 2004. Ekonomi Sumberdaya Alam dan Lingkungan. Jakarta. Gramedia.

Hoessin B dan Prasodjo E. 2009. Konsep pembagian kewenangan (urusan) antar tingkat pemerintahan. http://www.desentralisasi.org. [2 Juni 2009]

IDS. 2006. Understanding Policy Processes A Review of IDS research on the Environment. Knowledge, Technology and Society Team. UK. Institute of Development Studies at the University of Sussex Brighton BN1 9RE.

IPCC. 2006. IPCC Guidelines for National Greenhouse Gas Inventories. Prepared by the National Greenhouse Gas Inventories Programme. Eggleston H.S, Buendia L, Miwa K, Nagara T and Tanabe K (editor). Japan. IGES.

Kartodihardjo H. 2006. Ekonomi dan Institusi Pengelolaan Hutan. Telaah Lanjut Analisis Kebijakan Usaha Kehutanan. Bogor.Penerbit Ideal.

Keeley, J. And Scoones, I. 2003. Understanding environmental policy processes: cases from Africa. London: Earthscan.

Ngakan PO, Achmad A, Lahae K, Komarudin H dan Tako A. 2007. Implikasi Perubahan Kebijakan Otonomi Daerah terhadap Beberapa Aspek di Sektor 
Proses Pembuatan Kebijakan Pembagian Kewenangan antara ... Sulistya EKawati, Hariadi Kartodihardjo, Hardjanto, Haryatno Dwiprabowo ${ }^{\star}$ DodiK Ridfo N Nurrochmat

Kehutanan. Studi Kasus di Kabupaten Luwu Sulawesi Selatan. Bogor. CIFOR.

Parson,W. 2008. Public Policy. Pengantar Teori dan Praktik Analisis Kebijakan. Wibowo T (penerjemah). Judul asli: Public Policy:An Introduction to the Theory and Practice of Policy Analysis. Prenada Media Group. Jakarta.

Sutton, 1999. The policy process : An overview. Working Paper 18. Agustus 1999. Porland House Stag Place.London. Overseas Development Institute

Yayasan Penguatan partisipasi dan inisiatif dan kemitraan masyarakat Indonesia (YAPPIKA), Partnership Kemitraan dan FLEGT. (2003). Hasil laporan konteks historis perubahan UU pemerintah daerah (UU No 22/1999 menjadi UU No.32/2004). http://yappika.or.id. Diakses 25 Oktober 2010.

Wittmer H and Birner R. 2003. Between Conservationism, Eco-Populism and Developmentalism Discourses in Biodiversity Policy in Thailand and Indonesia. Institute of Rural Development Georg-August University of Göttingen. Jerman. 